\title{
PENDAFTARAN PERALIHAN HAK MILIK ATAS TANAH KARENA PEWARISAN
}

\author{
Christiana Sri Murni \\ Dekan Fakultas Hukum, Universitas Flores, Jln. Sam Ratulangi, Ende, Flores \\ srimurni.uniflor@gmail.com
}

\begin{abstract}
Abstrak
Pasal 20ayat (2) Undang-Undang Nomor 5 Tahun 1960 tentang Peraturan Dasar Pokok-Pokok Agrari, yang menyatakan: "Hak milik dapat beralih dan dialihkan kepada pihak lain". Jika orang yang mempunyai hak atas tanah meninggal dunia, maka yang menerima tanah itu sebagai warisan wajib meminta pendaftaran peralihan hak tersebut dalam waktu 6 bulan sejak meninggalnya orang itu. Pendaftaran peralihan hak karena pewarisan diwajibkan dalam rangka memberi perlindungan hukum kepada para ahli waris dan demi ketertiban tata usaha pendaftaran tanah, agar data yang tersimpan dan disajikan selalu menunjukkan keadaan yang mutakhir.Lebih lanjut Pasal 36 Peraturan Pemerintah Republik Indonesia Nomor 24 Tahun 1997 tentang Pendaftaran Tanah, menyatakan Pemeliharaan data pendaftaran tanah dilakukan apabila terjadi perubahan pada data fisik atau data yuridis objek pendaftaran tanah yang telah terdaftar. Pemegang hak yang bersangkutan wajib mendaftarakan perubahan. Permasalahannya bagaimanakah pendaftaran peralihan hak milik atas tanah karena pewarisan. Caranya adalah Penerima warisan mengajukan permohonan kepada Kantor Pertanahan dengan melengkapi persyaratan materiil sebagai ahli waris, memenuhi syarat sebagai subjek hak atas tanah yang menjadi objek pewarisan dan syarat formil adalah adanya surat keterangan kematian pemegang hak atas tanah (pewaris) yang diterbitkan oleh instansi yang berwenang dan surat keterangan sebagai ahli waris yang diterbitkan oleh instansi yang berwenang. Pasal 61 ayat (3) Peraturan Pemerintah Nomor 24 Tahun 1997 tentang Pendaftaran Tanah, "untuk pendaftaran peralihan hak karena pewarisan yang diajukan dalam waktu 6 (enam) bulan sejak tanggal meninggalnya pewaris, tidak dipungut biaya pedaftaran”. Selanjutnya berdasarkan permohonan penerima warisanKepala Kantor Pertanahan Kabupaten/kota yang wilayah kerjanya meliputi letak tanah yang bersangkutan melakukan perubahan nama pemegang hak atas tanah dalam sertifikat hak atas tanah dari atas nama pewaris menjadi atas nama ahli waris selanjutnya sertifikat hak atas tanah diserahkan kepada pemohon pendaftaran tanah.
\end{abstract}

\section{Kata kunci :Pendaftaran, Hak Milik Atas Tanah, Pewarisan}

\section{Abstract}

Article 20 paragraph (2) of Laws Number 5 of 1960 concerning Basic Agrarian Principles states: "Property rights can be transferred and transferred to other parties. "If the person who has rights to the land dies, then it is obligatory to the person who receives the land as an inheritance to ask for registration of the transfer of rights within 6 months after the death of the person. The registration of the transfer of rights due to inheritance is required in order to provide legal protection to the heirs and to order the land registration procedure. Article 36 of the Republic of Indonesia Government Regulation Number 24 of 1997 concerning Land Registration states that the maintenance of land registration data is carried out if there is a change in the physical data or juridical data of the registered land registration object, the relevant right holder must register the changes. The question is 
how the registration transfer of ownership rights to land due to inheritance is conducted. The way the registration is conducted beginsby the submission of the applicationby the inheritance recipient to the Land Office by means of completing the material requirements as heirs, followed by the fulfillment of the requirements as the subject of land rights that are the object of inheritance, and the formal requirement is the existence of a certificate of death of the land rights holder; a certificatee as an heir issued by the competent authority. Article 61 paragraph (3) Government Regulation Number 24 of 1997 concerning Land Registration, "for registration of transfer of rights due to inheritance submitted within 6 (six) months from the date of death of the testator, no registration fee is collected". Furthermore, based on the recipient's inheritance request, the Head of the Regency / City Land Office, whose working area covers the location of the land concerned, changes the name of the holder of land rights in the name of the heir to the name of the heir, then the land title.

\section{Keywords: Registration, Property Rights on Land, Inheritance}

\section{A. Pendahuluan}

Hak milik sangat penting bagi manusia untuk dapat melaksanakan hidupnya di dunia. Semakin tinggi nilai hak milik atas suatu benda, semakin tinggi pula penghargaan yang diberikan terhadap benda tersebut.Tanah adalah salah satu milik yang sangat berharga bagi umat manusia.Hak milik atas tanah sebagai salah satu jenis hak milik, sangat penting bagi negara, bangsa, dan rakyat Indonesia sebagai masyarakat agraria yang sedang membangun kearah perkembangan industri dan lainlain. Untuk itu di Indonesia Tanah merupakan masalah yang paling pokok, banyak perkara perdata maupun pidana yang diajukan ke pengadilan yang obyeknya sengketanya adalah tanah. Sengketa tersebut antara lain menyangkut sengketa utang piutang dengan tanah sebagai jaminan, sengketa tata usaha negara mengenai penerbitan sertifikat tanah, perbuatan melawan hukum, sengketa warisan misalnya tanah yang diwariskan kepada satu pihak, namun pihak lain yang telah mendaftarkan tanah tersebut dan memperoleh sertifikat walaupun bukan pewaris yang sah dari tanah yang disengketakan. Sengketa tanah warisan sering terjadi pada sengketa sertifikat ganda. Suatu hak bersama yang diperoleh dari warisan perlu dibagi sehingga menjadi hak individu. Kesepakatan antara pemegang hak bersama tersebut perlu dituangkan dalam akta Pejabat Pembuat Akta Tanah (PPAT) yang akan menjadi dasar pendaftarannya. Pendaftaran peralihan hak atas tanah sangat penting.Sengketa berkaitan dengan hak milik atas tanah karena warisan sering terjadi karena setelah meninggalnya pewaris, para ahli warisnya tidak segera mendaftarkan peralihan hak atas tanah.

Pasal 20ayat (2) UndangUndang Nomor 5 Tahun 1960 tentang Peraturan Dasar Pokok-Pokok Agraria (UUPA) menyatakan: "Hak milikatas tanah dapat beralih dan dialihkan kepada pihak lain". Dalam hal ini penerimahak yang baru wajib mendaftarkan peralihan hak milik atas tanah yang diterimanya dalam rangka memberikan perlindungan hak kepada pemegang hakatas tanah yang baru demi ketertiban tata usaha pendaftaran tanah. ${ }^{1}$

\footnotetext{
${ }^{1}$ Undang-Undang Nomor 5 Tahun 1960 tentang Peraturan Dasar Pokok-Pokok Agraria (UUPA), Pasal 20ayat (2)
} 
Pendaftaran hakatas tanah karena pewarisan tanah wajib dila kukan oleh pemegang hak atas tanah yang memperoleh warisan. Kewajiban tersebut telah diatur dalam Pasal 20 ayat(1) Peraturan Pemerintah Republik Indonesia Nomor 10 Tahun 1961 tentang Pendaftaran Tanah, yang menyatakan : "Jika orang yang mempunyai hak atas tanah meninggal dunia,maka yang menerima tanah itu sebagai warisan, wajib meminta pendaftaran peralihan hak tersebut dalam waktu 6 bulan sejak tanggal meninggalnya orang itu". ${ }^{2}$

Pendaftaran peralihan hak karena pewarisan diwajibkan dalam rangka memberi perlindungan hukum kepada para ahli waris dan demi ketertiban tata usaha pendaftaran tanah, agar data yang tersimpan dan disajikan selalu menunjukkan keadaan yang mutakhir. Peralihan hak milik atas tanah dapat terjadi karena perbuatan hukum dan peristiwa hukum. Peralihan hak milik atas tanah karena perbuatan hukum dapat terjadi apabila pemegang hak milik atas tanah dengan sengaja mengalihkan hak yang dipegangnya kepada pihak lain. Sedangkan peralihan hak milik atas tanah karena peristiwa hukum, terjadi apabila pemegang hak milik atas tanah meninggal dunia, maka dengan sendirinya atau tanpa adanya suatu perbuatan huku$\mathrm{m}$ disengaja dari pemegang hak, hak milik beralih kepada ahli waris pemegang hak.

Pewarisan hak milik atas ta-nah tetap harus berlandaskan pada ketentuan Undang - undang Pokok Agraria dan Peraturan Pelaksanaannya. Penerima peralihan hak milik atas tanah atau pemegang hak milik

${ }^{2}$ Peraturan Pemerintah Republik Indonesia Nomor 10 Tahun1961tentang Pendaftaran Tanah, Pasal 20 ayat(1) atas tanah yang baru haruslah berkewarganegaraan Indonesia sesuai dengan ketentuan Pasal 9 Undangundang Nomor 5 Thun 1960 tentang Peraturan Dasar Pokok-Pokok Agraria dan Pasal 21 ayat (1) UUPA bahwa warga Negara Indonesia saja yang dapat mempunyai hak milik, dengan tidak membedakan kesempatan antara laki-laki dan wanita yang mempunyai kesempatan yang sama untuk memperoleh suatu hak atas tanah serta untuk mendapat manfaat dan hasilnya, baik bagi diri sendiri maupun keluarganya. ${ }^{3}$

Kenyataan yang terjadi di masyarakat masih dijumpai adanya ahli waris yang menerima sebidang tanah dari pewaris yang belum mendaftarkan peralihan hak milik atas tanah dalam waktu 6 bulan setelah orang tuanya (pewaris) meninggal dunia. Ahli waris yang belum mendaftarkan peralihan hakatas tanah warisan tersebut dapat berakibat adanya sengketa tanah diantara para ahli waris yang berkepanjangan.

Peralihan hak atas tanah merupakan perbuatan hukum untuk memindahkan hak atas tanah kepada pihak lain. Pemindahan dilakukan apabila status hukum pihak yang akan menguasai tanah memenuhi persyaratan sebagai pemegang hak atas tanah yang tersedia, dan pemegang hak atas tanah tersebut bersedia untuk memindahkan haknya. Peralihan hak karena pewarisan terjadi karena hukum pada saat pemegang hak meninggal dunia.Sejak itu para ahli waris menjadi pemegang haknya yang baru.Terdapat Ahli waris selama ini belum melakukan pendaftaran hak milik atas tanah wari-

\footnotetext{
${ }^{3}$ Undang-Undang Nomor 5 Tahun 1960 tentang Peraturan Dasar Pokok-Pokok Agraria (UUPA), Pasal 21 ayat (1)
} 
san disebabkan karena kurang memahami tentang prosedur pendaftaran peralihan hak milik atas tanah pewarisan. Berdasarkan uraian tersebut di atas maka penulis dapat merumuskan permasalahannya : Bagaimanakah pendaftaran peralihan hak milik atas tanah karena pewarisan.

\section{PEMBAHASAN}

1. Pewaris, ahli waris dan harta warisan.

Menurut Soerojo Wignjodipoero bahwa "warisan adalah soal apakah dan bagaimanakah perbagai hak-hak dan kewajiban-kewajiban tentang kekayaan seseorang pada waktu ia meninggal dunia akan beralih kepada orang lain yang masih hidup. Warisan merupakan cara penyelesaian hubungan hukum dalam masyarakat yang melahirkan sedikit banyak kesulitan sebagai akibat dari wafatnya seorang manusia, dimana manusia yang wafat itu meninggalkan harta kekayaan". ${ }^{4}$

Istilah warisan diartikan sebagai cara penyelesaian bukan diartikan bendanya. Kemudian cara penyelesaian itu sebagai akibat dari kematian seseorang.Hal yang penting dalam masalah warisan ini adalah bahwa pengertian warisan itu memperlihatkan adanya tiga unsur yang masing-masing merupakan unsur yang esensial (mutlak), yakni:

1) Seorang peninggal warisan yang pada saat wafatnya meninggalkan harta kekayaan.

2) Seorang atau beberapa orang ahli waris yang berhak menerima kekayaan yang ditinggalkan ini.

${ }^{4}$ Soerojo Wignjodipoero, 1995, Pengantar dan AzasAzas Hukum Adat, Haji Masagung, Jakarta, Hlm 34.
3) Harta warisan atau harta peninggalan, yaitu kekayaan "in concreto" yang ditinggalkan dan sekali beralih kepada para ahli waris itu ${ }^{5}$

Hukum Waris adalah suatu hukum yang mengatur peninggalan harta seseorang yang telah meninggal dunia diberikan kepada yang berhak, seperti keluarga dan masyarakat yang lebih berhak. Salah satu sebab berakhirnya kepemilikan seseorang atas tanah adalah karena kematian. Karena dengan adanya peristiwa hukum ini mengakibatkan adanya peralihan harta kekayaan dari orang yang meninggal, baik harta kekayaan material maupun imamterial kepada ahli waris orang yeng meninggal tersebut. Dengan meninggalnya seseorang ini maka akan ada pewaris, ahli waris dan harta kekayaan. Pewarisan hanya berlangsung karena kematian. ${ }^{6}$

Pewaris adalah orang yang meninggal dunia dengan meninggalkan kekayaan/harta benda. Yang dapat diwariskan hanyalah Hak atas harta kekayaan, baik yang berupa hak maupun kewajiban sepanjang yang berwujud harta benda dan dapat dinilai dengan uang termasuk hak kekayaan intelektual pewaris sedangkan yang tidak dapat diwariskan adalah: Kedudukan atau jabatan; Hak dan kewajiban yang lahir dari hubungan hukum keluarga, kecuali atas hak ayah untuk menyangkali keabsahan anaknya atau hak anak untuk menuntut supaya dinyatakan sebagai anak sah dari bapak/ibunya. Hal-Hal yang dapat diwariskan ialah Hak-hak dan kewajibankewajiban di lapangan hukum kekayaan, yang dapat dinilai dengan

${ }^{5}$ Prodjojo Hamidjojo, 2000,Hukum Waris Indonesia, Stensil,Jakarta. Hlm.37

${ }^{6}$ Pasal 830 KUH Perdata 
uang. Pewaris adalah orang yang meninggal dunia dan meninggalkan harta kekayaan, sedangkan ahli waris adalah orang yang berhak atas harta kekayaan dari orang meninggal. Dan harta kekayaan yang ditinggalkan bisa immaterial maupun material, harta kekayaan material antara lain tanah, rumah ataupun benda lainnya.

Sedangkan Harta warisan menurut Hukum Perdata, tidak otomatis harta yang ditinggalkan oleh pewaris adalah harta warisan.Untuk mengetahui dan memastikan mengenai apakah harta yang ditinggalkan tersebut merupakan bagian dari harta warisan atau tidak, maka perlu diketahui terlebih dahulu status hukum perkawainannya dan hal-hal lain yang membebani harta yang ditinggalkan oleh orang yang telah meninggal dunia tersebut.

Menurut Hukum Perdata, pembagian ahli waris dikelompokkan menjadi dua kelompok. Kelompok pertama adalah kelompok yang oleh hukum atau Undang-Undang/KUHPerdata telah ditentukan sebagai ahli waris dan kelompok kedua adalah orang-orang yang menjadi ahli waris karena pewaris dikala hidupnya melakukan perbuatan hukum tertentu, misalnya pengakuan anak, pengangkatan/adopsi anak atau perbuatan hukum lain yang disebut testament atau surat wasiat.

Menurut Undang-undang yang berhak untuk menjadi ahliwaris ialah para keluarga sedarah, baik sah, maupun luarkawin dan si suami atau isteri yang hidup terlama, semua menurut peraturan Pasal $832 \mathrm{KUH}$ perdata $^{7}$

Ahli waris menurut undangundang terdiri dari empat kelompok. Kelompok pertama terdiri suami at- au istri yang hidup terlama ditambah anak atau anak-anak serta keturunan dari anak-anak tersebut. Kelompok ini diatur di dalam Pasal 832 dan 852 KUHPerdata.Kelompok kedua terdiri atas ayah dan ibu kandung (apabila keduanya rnasih hidup), ayah atau ibu (apabila salah satunya telah meninggal dunia) dan saudara atau saudari beserta keturunan dari saudara atau saudari tersebut. Kelompok kedua ini diatur di dalarn Pasal 854 s/d Pasal 857 KUHPerdata. Sedangkan kelompok ketiga terdiri atas kakek dan nenek dari garis ibu dan kakek dan nenek dari garis bapak.Golongan ini diatur di dalam Pasal 850 dan Pasal 853 KUHPerdata. Kelompok terakhir ke 4 (keempat) terdiri dari sanak keluarga pewaris yang lainnya dan diatur di dalam Pasal 858 dan Pasal 861 KUHPerdata.

Pewarisan dapat terjadi kare-na ketentuan undang-undang ataupun karena wasiat dari orang yang mewasiatkan. Menurut Undang-undang yang berhak untuk menjadi ahliwaris ialah para keluarga sedarah, baik sah, maupun luarkawin dan si suami atau isteri yang hidup terlama semua menurut peraturan Pasal 832 KUH Perdata. ${ }^{8}$

Para ahli waris menerima hak terdahulu untuk pendaftaran boedel ataupun menolak warisan tersebut. Menurut Pasal 1023 KUH Perdata menyatakan " semua orang yang memperoleh hak atas suatu warisan, dan ingin menyelidiki keadaan harta peninggalan, agar mereka dapat mempertimbangkan apakah akan bermanfaat bagi mereka, untuk menerima warisan itu secara murni, atau dengan hak istimewa dengan mengadakan pendaftaran peninggalan, atau pula untuk menolaknya, mem- 
punyai hak untuk memikir, dan mereka harus melakukan suatu pernyataan di kepaniteraan Pengadilan Negeri, yang di dalam wilayahnya telah jatuh meluang warisan tersebut, pernyataan mana akan dilakukan dalam suatu register yang disediakan untuk itu " 9

Lebih lanjut Pasal 1024 KUH Perdata menyatakan " kepada waris yang bersangkutan diberikan suatau jangka waktu selama empat bulan terhitung mulai hari tanggal pernyataan yang diperbuat tersebut, untuk menyuruh mengadakan pendaftaran tentang harta peninggalannya dan untuk memikir. ${ }^{10}$

Dengan jatuhnya tanah kepada para ahli waris, terjadilah pemilikan bersama tanah hak milik jika tanah tersebut hanya satu-satunya. Akan tetapi jika pewaris memiliki tanah tersebut sesuai dengan jumlah ahli waris dan telah dibuatkan surat wasiat, maka tanah dimaksud telah menjadi milik masing-masing ahli waris. Untuk memperoleh kekuatan pembuktian tanah dari hasil pewarisan, maka surat keterangan waris sangat diperlukan disamping sebagai dasar untuk pendaftaran tanahnya.

Namun sampai saat ini untuk memperoleh surat keterangan waris, hukum yang berlaku bagi WNI masih berbeda-beda. Sejak berlakunya Peraturan Pemerintah Nomor 10 Tahun 1961 tentang Pendaftaran Tanah, dan sesuai dengan Pasal 25, surat keterangan warisan itu merupakan suatu keharusan. Hanya saja, pejabat yang berwenang untuk membuat surat keterangan warisan itubelum ditentukan. Untuk menyeragamkan masalah surat keterangan waris, dengan memperhatikan penggolongan warga negara, maka golongan keturunan Eropa,

\footnotetext{
${ }^{9}$ Pasal 1023 KUH Perdata

${ }^{10}$ Pasal 1024 KUH Per

surat keterangan waris dibuatkan oleh Notaris. Golongan penduduk Asli/Pribumi, surat keterangan waris oleh para ahli waris, disaksikan oleh Lurah diketahui Camat. Golongan keturunan Tionghoa oleh Notaris. Golongan keturunan Timur Asing lainnya (seperti India dan Arab) surat keterangan waris dibuat oleh Balai Harta peninggalan. ${ }^{11}$

Menurut A.P Parlindungan, untuk ke empat golongan tersebut dapat juga diganti dengan keputusan pengadilan negeri dan bagi golongan Bumi putra Islam dengan surat Keputusan Pengadilan agama atau Mahkamah Syariah. ${ }^{12}$ Bagi golongan Timur Asing Cina termasuk juga mereka yang sudah menjadi warga negara Indonesia maupun yang masih Warga Negara Asing (WNA), surat keterangan kewarisan nya dibuat oleh notaris. ${ }^{13}$ Namun di daerah tertentu di Jawa Barat, surat keterangan waris dibuat oleh Kotamadya berdasarkan ketentuan daerah masing-masing. ${ }^{14}$

Dalam hukum perdata jika pemegang suatu hak atas tanah meninggal dunia, maka hak tersebut akan beralih kepada ahli waris karena secara otomatis hukum akan berpindah kepada ahli warisnya. Peralihan tersebut terjadi kepada para ahli warisnya yaitu siapa-siapa yang termasuk ahli waris. Diberikan bagian masing-masing dan bagaimana cara membaginya diatur dalam hukum waris, almarhum pemegang hak yang bersangkutan bukan oleh hukum tanah yang bersangkutan. Hak atas tanah yang dapat beralih atau dialihkan adalah Hak

\footnotetext{
${ }^{11}$ Surat Direktur pendaftaran tanah, direktur Jenderal Agraria Departemen Dalam Negeri Nomor DPT/12/63/12/69

${ }^{12}$ A.P Parlindungan, berakhirnya hak-hak atas tanah menurut sistem UUPA, cetakan III, Bandung :

Mandar Maju, 2001, Hlm 24.

${ }^{13}$ Ibid hlm 73

${ }^{14}$ Ibid hlm 143
} 
Milik, Hak Guna Usaha, Hak Guna Bangunan, Hak Pakai, Hak milik atas satuan rumah susun (Pasal 2 ayat (3 UU No.21 Tahun 1997). Selanjutnya pembahasan dalam tulisan ini yang dialihkan berkaitan Hak milik.

\section{Pendaftaran Peralihan Hak Mi- lik Atas Tanah Karena Warisan}

Pendaftaran tanah dikenal dengan Recht Kadaster. Ketentuan pendaftaran tanah di Indonesia diatur dalam Pasal 19 Peraturan Dasar Pokok-pokok Agraria (UUPA) yang dilaksanakan dengan Peraturan Pemerintah Nomor 24 Tahun 1997 tentang Pendaftaran Tanah. Tujuan pendaftaran tanah sebagaimana diatur dalam Pasal 3 Peraturan Pemerintah Nomor 24 Tahun 1997 tentang Pendaftaran Tanah adalah "untuk memberikan kepastian dan perlindungan hukum kepada pemegang hakhak atas sebidang tanah, satuan rumah susun dan hak-hak lain yang terdaf-tar agar dengan mudah dapat membuktikan dirinya sebagai pemegang hak yang bersangkutan". Kepastian hukum atas objek bidang tanah, yaitu mengenai letak batas-batas dan luasnya. Kepastian hukum atas subjek haknya, yaitu siapa yang menjadi pemiliknya dan kepastian hukum atas jenis hak atas tanahnya. Kepastian data fisik dan yuridis harus jelas. Oleh karena itu data fisik dan data yuridis mengenai bidang tanah yang sudah dinilai cukup untuk dibukukan tetap dibukukan walaupun ada data yang masih harus dilengkapi atau ada keberatan dari pihak lain mengenai data itu. Dengan demikian setiap data fisik dan data yuridis mengenai bidang tanah itu, termasuk adanya sengketa mengenai data itu, semua tercatat.Peralihan hak milik atas tanah diatur dalam Pasal 20 ayat 2 UUPA yaitu hak milik dapat beralih dan dialih- kan kepada pihak lain. Hak milik atas tanah disebutkan dalam Pasal 16 ayat (1) huruf a Undang-Undang Nomor 5 Tahun 1960 tetang Peraturan Dasar Pokok-Pokok Agraria atau lebih dikenal dengan sebutan Undang-Undang Pokok Agraria (UUPA).

Sesuai dengan ketentuan $\mathrm{Pa}$ sal 19 Peraturan Dasar Pokok-Pokok Agraria (UUPA) pendaftaran tanah diselenggarakan oleh Badan Pertanahan Nasional dan tugas pelaksanaan pendaftaran dilakukan oleh kepala kantor pertanahan di daerah-daerah. Dalam melaksanakan pendaftaran tanah, kepala kantor pertanahan dibantu oleh Pejabat Pembuat Akta Tanah (PPAT) dan pejabat lain yang ditugaskan melaksanakan kegiatan tertentu menurut Peraturan Pemerintah Nomor 24 Tahun 1997 dan peraturan-perundangan yang berlaku. Dalam melakukan pendaftaran tanah secara sistematik, kepala kantor pertanahan dibantu oleh panitia ajudikasi yang dibentuk oleh menteri atau pejabat yang ditunjuk. Sedangkan pendaftaran tanah secara sporadic dilaksanakan atas permintaan pihak yang berkepentingan. Penyelenggara pendaftaran tanah secara garis besar meliputi kegiatan pendaftaran tanah pertama kali dan pemeliharaan data pendaftaran tanah. Kedua hal tersebut sama pentingnya, karena kurang perhatian terhadap salah satu dari keduanya akan menimbulkan halhal yang tidak di harapkan kemudian hari. Sedangkan pendaftaran tanah dilakukan oleh Kepala Kantor Pendaftaran Tanah dengan dibantu oleh PPAT dan pejabat lain yang ditugaskan untuk melaksanakan kegiatan-kegiatan tertentu. Dalam hal ini pendaftaran tanah sistematis kepala kantor pertanahan dibantu oleh panitia Ajudikasi. Penunjukan 
Panitia Ajudikasi untuk membantu tugas Kepala Kantor Pertanahan dalam pendaftaran tanah sistematis dimaksud agar tugas-tugas rutin para kepala kantor pertanahan tidak terganggu, mengingat kegiatan pendaftaran tanah secara sistematis pada umumnya bersifat massal Pemeliharaan Data Pendaftaran Tanah Kegiatan pemeliharaan data pendaftran tanah meliputi Pendaftaran Peralihan dan Pembebanan Hak dan Pendaftaran Perubahan Data Pendaftaran Tanah (Pasal 36 sd 57 PP No. 24 tahun 1997). Pemeliharaan data pendaftaran tanah dilakukan apabila terjadi perubahan pada data fisik ataupun data yuridis obyek pendaftaran tanah yang telah didaftar. Perubahan data fisik dimaksud adalah pemisahan, pemecahan atau penggabungan bidang-bidang tanah yang sudah terdaftar. Perubahan data yuridis terjadi apabila ada pembebanan atau pemindahan hak atas tanah yang sudah didaftar. Perubahan yang terjadi oleh pemegang hak atas tanah wajib didaftarkan pada kantor pertanahan. Pendaftaran Tanah Kedua Kali yakni Pendaftaran tanah kedua kali ini yang memuat pembaruan isi sertifikat seperti jenis sertIfikat, nama pemilik hak dan pemegang hak, maupun yang terkait dengan bidang tanah. Berdasarkan jenis permohonan sertifikat, pendaftaran tanah kedua kali ini dibedakan menjadi tiga; penggantian sertifikat karena rusak, pendaftaran peningkatan hak dan peralihan karena waris atau hibah.

Sedangkan Pengertian Peralihan Hak Atas Tanah menurut Kamus Besar Bahasa Indonesia adalah memindahkan sedangkan hak berarti benar. Jadi peralihan hak atas tanah adalah memindahkan atau beralihnya penguasaan tanah yang semula milik sekelompok masyarakat ke masyarakat lainnya. Peralihan tersebut dapat dilakukan dengan cara menukar/ memindahkan tanah. Penguasaan yuridis dilandasi hak yang dilindungi oleh hukum dan umumnya memberi kewenangan kepada pemegang hak untuk menguasan secara fisik tanah yang dihaki. Tetapi ada juga penguasaan yuridis yang biarpun memberi kewenangan untuk menguasai tanah yang dihaki secara fisik, pada Kenyataannya penguasaan fisiknya dilakukan pihak lain. Beralihnya atau berpindahnya hak kepemilikan sebidang tanah atau beberapa bidang tanah dari pemilik semula kepada pemilik yang baru karena sesuatu atau perbuatan hukum tertentu. Perbuatan hukum pemindahan hak bertujuan untuk memindahkan hak atas tanah kepada pihak lain untuk selama-lamanya (dalam hal ini subyek hukumnya memenuhi syarat sebagai pemegang hak atas tanah). Perbuatan hukum dapat diartikan sebagai setiap perbuatan yang dilakukan oleh subyek hukum yang menimbulkan akibat hukum.

Perbuatan hukum itu terdiri dari Perbuatan hukum sepihak, yaitu perbuatan hukum yang dilakukan oleh satu pihak saja dan menimbulkan hak dan kewajiban pada satu pihak pula, misalnya pembuatan surat wasiat, dan pemberian hadiah sesuatu (benda). Perbuatan hukum dua pihak, ialah perbuatan hukum yang dilakukan oleh dua pihak dan menimbulkan hak dan kewajibankewajiban bagikedua pihak (timbal balik) missalnya membuat persetujuan jual beli, sewa menyewa dan lain-lain.

Syarat materiel peralihan hak atas tanah baik yang beralih maupun dialihkan

a) Syarat materiil dalam pewarisan tanah adalah ahli waris harus memenuhi syarat sebagai subjek 
hak atas tanah yang menjadi objek pewarisan.

b) Syarat materiel dalam jual beli tanah adalah pemilik tanah atau pemegang hak atas tanah sebagai penjual berhak dan berwenang menjual hak atas tanahnya, sedangkan pembeli harus memenuhi syarat sebagai subyek hak atas tanah yang menjadi objek jual beli tanah.

c) Syarat materiel dalam tukar menukar tanah adalah kedua belah pihak sebagai pemegang hak atas tanah berhak dan berwenang menukarkan hak atas tanahnya , serta memenuhi syarat sebagai subyjek hak atas tanah yang menjadi objek tukar menukar tanah.

d) Syarat materiel dalam hibah tanah adalah pemilik tanah atau pemegang hak atas tanah sebagai pemberi hibah berhak dan berwenang menghibahkan hak atas tanahnya , sedangkan pihak lain sebagai penerima hibah memenuhi syarat sebagai subjek hak atas tanah yang menjadi objek hibah tanah.

e) Syarat materiel dalam pemasukan dalam modal perusahaan adalah pemilik tanah atau pemegang hak atas tanah sebagai pihak yang menyerahkan tanah berhak dan berwenang menyerahkan hak atas tanahnya, sedangkan ahaan sebagai penerima hak atas tanah harus memenuhi syarat sebagai subjek hak atas tanah yang menjadi objek pemasukan dalam modal perusahaan.

f) Syarat materiel dalam lelang tanah adalah Kantor lelang sebagai penjual lelang tanah berhak dan berwenang menjual tanah, sedangkan pembeli lelang harus memenuhi syarat sebagai subjek hak atas tanah yang menjadi objek lelang tanah.
Adapun syarat formal peralihan hak atas tanah baik yang beralih maupun dialihkan.

a) Syarat folmal dalam pendaftaran pewarisan tanah, adalah adanya surat keterangan kematian pemegang hak atas tanah (pewaris) yang diterbitkan oleh instansi yang berwenang dan surat keterangan sebagai ahli waris yang diterbitkan oleh instansi yang berwenang.

b) Syarat formal dalam pendaftaran jual beli, tukar menukar, hibah, dan pemasukan dalam modal perusahaan harus dibuktikan dengan akta yang dibuat oleh dan di hadapan Pejabat Pembuat Akta Tanah (PPAT) yang berwenang. Pasal 2 dan Pasal 3 Peraturan Pemerintah Nomor 37 Tahun 1998 tentang Peraturan Jabatan Pejabat Akta Tanah, akta-akta tanah yang kewenangan pembuatannya diserahkan kepada Pejabat Pembuat Akta tanah adalah : Akta Jual Beli, akta tukar menukar, akata hibah, akta pemasukan ke dalam perusahaan, akta pembagian hak bersama, akta pemberian hak guna bangunan, Hak pakai, atas tanah Hak Milik, akts pemberian hak Tanggungan, pemberian kuasa pembebanan hak tanggungan.

c). Syarat formal dalam pendaftaran lelang tanah, adalah lelang tanah harus dibuktikan dengan berita acara atau kutipan risalah lelang yang dibuat oleh pejabat dari kantor lelang.

Lebih lanjut, dalam $\mathrm{Pa}-$ sal 42 ayat (1) dan ayat (2) Peraturan Pemerintah Nomor $24 \mathrm{Ta}$ hun 1997 tentang Pendaftaran Tanah, mengatur tentang kewajiban ahli waris untuk mendaftar=kan peralihan hak karena pewarisan mengenai bidang tanah hak 
yang sudah didaftar dan yang belum didaftar,yaitu:

a) Untuk pendaftaran peralihan hak karena pewarisan mengenai bidang tanah yang sudah didaftar dan hak milikatas satuan rumah susun sebagai yang diwajibkan menurut ketentuan sebagaimana dimaksud dalam Pasal 36, wajib diserahkan oleh yang menerima hak atas tanah atau hak milikatas satuan rumah susun yang bersangkutan sebagai warisan kepada Kantor Pertanahan, sertifikat hak yang bersangkutan,surat kematian orang yang namanya dicatat sebagaipemegang haknya dan surat tanda bukti sebagai ahli waris.

b) Jika bidang tanah yang merupakan warisan belum didaftar, wajib diserahkanjuga dokumen-dokumen sebagaimanadimaksud dalam Pasal 39 ayat (1) huruf b.

c) Jika penerima warisan terdiri dari satu orang, pendaftaran peralihan hak tersebut dilalkukan kepada orang tersebut berdasarkan surat tanda bukti sebagai ahli waris sebagaimana dimaksud pada ayat (1).

d) Jika penerima warisan lebih dari satu orang dan waktu peralihan hak tersebut didaftarkan disertai dengan akta pembagian waris yang memuat keterangan bahwa hak atas tanah atau hak milik atas satuan rumah susun tertentu jatuh kepada seorang penerima warisan tertentu, pendaftaran peralihan hak atas tanah atau hak milik atas satuan rumahsusun itu dilakukan kepada penerima warisan yang bersangkutan berdasarkan surat tandabukti sebagai ahli waris dan akta pembagian waris tersebut.

e) Warisan berupa hak atas tanah atau hak milik atas satuan rumah susun yang menurut akta pembagian waris harus dibagi bersama antara beberapa penerima warisan atau waktu didaftarkan belum ada akta pembagian warisnya, didaftar peralihan haknya kepada para penerima waris yang berhak sebagai hak bersama mereka berdasarkan surat tanda bukti sebagai ahli waris dan /atau akta pembagian waris tersebut.

Cara Peralihan Hak Atas Tanah Peralihan hak atas tanah bisa terjadi karena pewarisan tanpa wasiat dan perbuatan hukum pemindahan hak, sebagai berikut: Pewarisan tanpa wasiat menurut hukum perdata jika pemegan sesuatu hak atas tanah meninggal, maka hak tersebut karena hukum beralih kepada ahli warisnya. Pemindahan hak berbeda dengan beralihnya hak atas tanah karena pewarisan tanpa wasiat yang terjadi karena peristiwa hukum dengan meninggalnya pemegang hak, dalam perbuatan hukum pemindahan hak, hak atas tanah yang bersangkutan sengaja dialihkan kepada pihak lain. Bentuk pemindahan haknya dapat berupa : Pewarisan dari ayah atau ibu kepada anak atau dari kakek-nenek kepada cucu atau dari adik kepada kakak atau sebaliknya kakak kepada adiknya dan lain sebagainya. Hibah yaitu pemberian dari seseorang kepada orang lain.

Pembagian hak bersama bisa terjadi karena hak yang ada terdaftar atas nama beberapa nama sehingga untuk lebih memperoleh kepastian hukum para pihak melakukan pembagian atas bidang tanah yang mereka miliki bersama-sama. Pelepasan hak, dilakukan karena calon pemegang hak yang akan menerima peralihan hak atas tanah tersebut adalah bukan orang atau pihak yang merupakan subjek hukum yang dapat menerima peralihan hak atas tanah yang akan dialihkan tersebut, sebagai contoh tanah yang akan di- 
lalihkan kepada suatu Badan Hukum Indonesia adalah tanah dengan status hak milik, ini tidak bisa dilakukan karena Badan Hukum Indonesia bukanlah Subjek hukum yang dapat menerima peralihan hak atas tanah dengan status hak milik. Untuk memperoleh surat bukti yang lebih kuat dan lebih luas daya pembuktiannya pemindahan haknya didaftarkan pada kantor pertanahan setempat letak tanah tersebut berada, dengan tujuan: Untuk memberikan kepastian hukum dan perlindungan hukum kepada pemegang hak yang terdaftar haknya, agar dengan mudah dapat membuktikan dirinya sebagai pemegang hak yang bersangkutan.

Pengertian dan sifat hak mi-lik atas tanah disebutkan dalam Pa-sal 20 ayat (1) yaitu " hak milik ada-lah hak turun-temurun, terkuat, terpenuh, yang dapat dipunyai orang atas tanah dengan mengingat ketentuan Pasal 6. Pasal 6 UUPA menyatakan "Hak milik mempunyai fungsi sosial."Turun temurun artinya hak milik atas tanah dapat berlangsung terus selama pemiliknya masih hidup dan bila pemiliknya meninggal dunia, maka hak milik atas tanah dapat diteruskan oleh ahli warisnya sepanjang ahli warisnya memenuhi syarat sebagai subyek hak milik.Terkuat artinya hak milik lebuh kuat bil dibandingkan dengan hak atas tanah lain, tidak mempunyai batas waktu tertentu, mudah dipertahankan dari gangguan pihak lain, dan tidak mudah dihapus. Terpenuh artinya Hak milik atas tanah memberi wewenang kepada pemiliknya paling luas bila dibandingkan dengan hak atas tanah lain, dapat mejadi induk bahi hak atas tanah yang lain, dan penggunaan tanahnya lebih luas bila dibandingkan dengan hak atas tanah yang lain, hak milik atas taah dimiliki oleh perseorangan warga negara Indonesia dan badanbadan hukum tertentu yang ditetapkan oleh Pemerintah.

Peralihan hak milik atas tanah diatur dalam Pasal 20 ayat (1) UUPA yaitu hak milik dapat beralih dan dialihkan kepada pihak lain. Dua bentuk peralihan hak milik atas tanah yaitu, "beralih dan dialihkan. Beralih artinya berpindahnya hak milik atas tanah dari pemiliknya kepada pihak lain disebabkan karena peristiwa hukum. Peristiwa hukum adalah meninggal dunianya pemiliknya, maka hak milik atas tanah secara yuridis berpindah kepada ahli warisnya sepanjang ahli warisnya memenuhi syarat sebagai subyek hak milik. Berpindahnya hak milik atas tanah ini melalui sesuatu proses pewarisan dari pemilik tanah sebagai pewaris kepada pihak lain sebagai ahli waris.

Selanjutnya dialihkan artinya berpindahnya hak milik atas tanah dari pemiliknya kepada pihak lain disebabkan oleh perbuatan hukum. Perbuatan hukum adalah perbuatan yang menimbulkan akibat hukum, contoh pewarisan, jual beli, tukar menukar, hibah, pemasukan dalam modal perusahaan (inbreng), lelang". ${ }^{15}$

Peralihan hak atas tanah merupakan berpindahnya hak atas tanah dari pemegang hak yang lama kepada pemegang hak yamg baru. Pasal 42 ayat (1) dan ayat (2) Peraturan PemerintahNomor 24 Tahun 1997 tentang Pendaftaran Tanah, mengatur tentang kewajiban ahli waris untukmendaftarkan peralihan hak karena pewarisan mengenai

\footnotetext{
${ }^{15}$ Urip Santoso, 2015, Perolehan Hak atas
} tanah, Prenadamedia Group, Jakarta, hlm 30-39 
bidang tanah hak yangsudah didaftar dan yang belum didaftar,yaitu:

a) Untuk pendaftaran peralihan hak karena pewarisanmengenai bidang tanah yang sudahdidaftar dan hak milikatas satuan rumah susun sebagai yang diwajibkan menurut ketentuan sebagaimana dimaksud dalam Pasal 36, wajib diserahkan oleh yang menerima hak atas tanah atau hak milikatas satuan rumah susun yang bersangkutan sebagai warisan kepada kantor pertanahan, sertifikat hak yang bersangkutan, surat kematian orang yang namanya dicatat sebagai pemegang haknyadan surattanda bukti sebagai ahli waris.

b) Jika bidang tanah yang merupakan warisan belum didaftar, wajib diserahkanjuga dokumendokumen sebagaimana dimaksud dalam Pasal 39 ayat (1) huruf b antara lain yaitu :Surat bukti hak, surat keterangan kepala desa/kelurahan yang menyatakan bahwa yang bersangkutan menguasai bidangtanah itu, Surat keterangan yang menyatakan bahwa bidang tanah yangbersangkutan belum bersertifikat dari kantor pertanahan, atauuntuk tanah yang terletak di daerah yang jauh dari kedudukan kantor pertanahan, dari pemegang hak yang bersangkutan dengan dikuatkan oleh kepala desa/kelurahan.

c) Jika penerima warisan terdiri dari satu orang pendaftaran peralihan hak tersebut dilakukan kepada orang tersebut berdasarkan surat tanda bukti sebagai ahli waris.

d) Jika penerima warisan lebih dari satu orang dan waktu peralihan hak tersebut didaftarkan disertai dengan akta pembagian waris yang memuat keterangan bahwa hak atas tanah atau hak milik atas satuan rumah itu dilakukan ke- pada penerima warisan yang bersangkutan berdasarkan surat tanda bukti sebagai ahli waris dan akta pembagiam waris tersebut.

e) Warisan berupa hak atas tanah atau hak milik atas satuan rumah susun yang menurut akta pembagian waris harus dibagi bersama antara beberapa penerima warisan atau waktu didaftarkan belum ada akta pembagian warisnya, didaftar peralihan haknya kepada para penerima waris yang berhak sebagai hak bersama mereka berdasarkan surat tanda bukti sebagai ahli waris dan/atau akta pembagian waris. ${ }^{16}$

Kewajiban ahli waris menurut Pasal 20 Peraturan Pemerintah Republik Indonesia Nomor 10 Tahun 1961 tentang Pendaftaran Tanah, menyebutkan bahwa : "Jika orang yang mempunyai hak atas tanah meninggal dunia, maka yang menerima tanah itu sebagai warisan wajib meminta pendaftaran peralihan hak tersebut dalam waktu 6 bulan sejak meninggalnya orang itu".

Setelah berlakunya Peraturan Pemerintah Republik Indonesia Nomor 24 Tahun 1997 tentang Pendaftaran Tanah, maka keterangan mengenai kewajiban untuk mendaftarkan peralihan hak milik atas tanah karena pewarisan diatur dalam Pasal 36 Peraturan Pemerintah tersebut. Pewarisan dapat terjadi karena ketentuan undang-undang ataupun karena wasiat dari orang yang mewasiatkan.

Menurut Pasal 1023 Kitab Undang-Undang Hukum Perdata, "para ahli waris menerima hak terdahulu untuk pendaftaran boedel ataupun menolak warisan

\footnotetext{
${ }^{16}$ Ibid, Hlm. 129-130
} 
tersebut". Dengan jatuhnya tanah kepada ahli waris, terjadilah pemilikan bersama tanah hak milik jika tanah tersebut hanya satusatunya. Untuk memperoleh kekuatan pembuktian tanah dari hasil pewarisan, maka surat keterangan waris sangat diperlukan disamping sebagai dasar untuk pendaftaran tanahnya. ${ }^{17}$

Menurut ketentuan Peraturan Pemerintah Nomor 10 tahun 1961 junto Peraturan Pemerintah Nomor 24 Tahun 1997 tentang Pendaftaran Tanah, yang berhak menerima warisan wajib meminta pendaftaran peralihan hak tersebut dalam jangka waktu 6 (enam) bulan sejak meninggalnya orang yang semula mempunyai hak milik tersebut dengan tidak melanggar ketentuan bahwa menerima hak milik atas tanah harus sesuai dengan Undang undang Pokok Agraria pasal 21. ${ }^{18}$

Peralihan hak atas tanah merupakan berpindahnya hak atas tanah dari pemegang hak yang lama kepada pemegang hak yamg baru. Ada 2 (dua) cara peralihan hak atas tanah, yaitu beralih dan dialihkan. Beralih menunjukkan berpindahnya hak atas tanah tanpa ada perbuatan hukum yang dilakukan oleh pemiliknya, misalnya melalui jual beli, dengan balik nama. Sedangkan dialihkan menunjuk pada berpindahnya hak atas tanah melalui perbuatan hukum yang dilakukan pemiliknya, misalnya warisan dari pewaris kepada ahli waris.Untuk peralihan hak milik atas tanah karena pewarisan yangbelum didaftarkan wajib diserahkan dokumen-dokumen yang di-

\footnotetext{
${ }^{17}$ Adrian Sutedi, 2014, Peralihan hak atas tanah dan pendaftarannya, Jakarta : Sinar Grafika. Hlm 102.

${ }^{18}$ Peraturan Pemerintah Nomor 10 tahun 1961 tentang Pendaftaran Tanah
}

atur dalam Pasal39 ayat (1) hurufb Peraturan Pemerintah Nomor 24 Tahun 1997 tentang Pendaftaran Tanah, yaitu :

1. Surat bukti hak sebagaimana dimaksud dalam Pasal 24 ayat(1) atau surat keterangan kepala de$\mathrm{sa} /$ kelurahan yangmenyatakan bahwa yang bersangkutan menguasai bidangtanah itu sebagaimana dimaksud Pasal 24 ayat (2), dan

2. Surat keterangan yang menyatakan bahwa bidang tanah yang bersangkutan belum bersertifikat dari kantor pertanahan, atau untuk tanah yang terletak di daerah yang jauh dari kedudukan kantor pertanahan, dari pemegang hak yang bersangkutan dengan dikuatkan oleh kepala desa/kelurahan.

Selanjutnya untuk pendafta-ran peralihan hak milik atas tanah karena pewarisan yang wajib dilakukan oleh pihak yang memperoleh tanah hak milik sebagai warisan diatur dalam Pasal 42 ayat (1) Peraturan Pemerintah Nomor 24 Tahun 1997 tentang Pendaftaran Tanah yang berbunyi sebagai berikut: "Untuk pendaftaran peralihan hak karena pewarisan mengenai bidang tanah hak yang sudah didaftar dan hak milik atas satuan rumah susun sebagai yang diwajibkan menurut ketentuan sebagaimana dimaksud dalam pasal 36, wajib diserahkan oleh yang menerima hak atas tanah atau hak milik atas satuan rumah susun yang bersangkutan, surat kematian orang yang namanya dicatat sebagai pmegang haknya dan surat tanda bukti sebagai ahli waris". 19

Untuk pembagian hak bersama, Psal 51 ayat (1) PP Nomor. 24

\footnotetext{
${ }^{19}$ Pasal 42 ayat (1) Peraturan Pemerintah Nomor 24 Tahun 1997 tentang pendaftaran tanah
} 
tahun 1997 menyebutkan: "Pembagian hak bersama atas tanah atau hak milik atas satuan rumah susun menjadi hak masing-masing pemegang hak bersama didaftra berdasarkan akta yang dibuat PPAT yang berwenang menurut peraturan yang berlaku yang membuktikan kesepakatan antara pemegang hak bersama mengenai pembagian hak bersama tersebut.'

Pada saatnya suatu hak bersama, baik yang diperoleh sebagai warisan maupun sebab lain perlu dibagi sehingga menjadi hakl individu. Untuk itu kesepkatan antara pemegang hak bersama tersebut perlu dituangkan dalam akta PPAT yang akan menjadi dasar bagi pendaftarannya. Dalam pembagiann tersebut tidak harus semua pemegang hak bersama memperoleh bagian.Dalam pembagian harta waris seringkali yang menjadi pemenagn hak individu hanya sebagian dari keseluruhan penerimaan warisan, asalkan hal tersebut disepakati oleh seluruh penerima warisan sebagai pemegang hak bersama.

Selanjutnya setelah ahli waris mendaftarkan peralihan hak milik atas tanahnya ke kantor Pertanahan, maka akan dikeluarkan pengumuman di kantor Pertanahan dan kantor Kepala Desa/Kelurahan dimana letak tanah yang bersangkutan berada. Pengumuman ini dilaksanakan selama 60 hari untuk memberi kesempatan kepada pihak yang berkepentingan mengajukan keberatan. Sertifikat akan diterbitkan sesuai dengan data fisik yaitu "keterangan mengenai letak, batas, dan luas bidang tanah dan satuan rumah susun yang didaftar, termasuk keterangan mengenai adanya bangunan atau bagian bangunan di atasnya dan data yuridis mengenai keterangan status hukum bidang tanah dan satuan rumah susun yang didaftar, pemegang hak dan pihak lain serta beban-beban lain yang membebaninya yang telah didaftar dalam buku tanah". ${ }^{20}$

Dari ketentuan di atas, apabila seseorang pemilik tanah meninggal dunia, maka orang yang menerima warisan itu dalam waktu 6 (enam) bulan harus mendaftarkan tanah warisannya tersebut ke Badan Pertanahan Nasional, waktu 6 (ena$\mathrm{m})$ bulan itu dapat diperpanjang oleh Badan Pertanahan Nasional.

Menurut ketentuan Pasal 61 ayat (3) Peraturan Pemerintah Nomor 24 Tahun 1997 tentang Pendaftaran Tanah, "untuk pendaftaran peralihan hak karena pewarisan yang diajukan dalam waktu 6 (enam) bulan sejak tanggal meninggalnya pewaris, tidak dipungut biaya pedaftaran". Sesuai dengan pasal tersebut di atas, bahwa penerima warisan (ahli waris) harus mendaftarakan tanahnya ke Kantor Pertanahan.Tetapi harus diperhatikan terlebih dahulu apakah tanahnya tersebut sudah dibukukan atau belum.

Untuk tanah yang telah dibukukan maka yang perlu diserahkan ke Kantor Pertanahan adalah: Sertifikat pewaris, Surat keterangan meninggal dunia dari Kepala Desa atau Lurah. Untuk memperoleh surat tersebut, ahli waris atau para ahli waris memohon surat yang disahkan oleh Ketua Rukun Tetangga (RT) dan diketahui oleh Kepala Rukum Wara (RW) dan dua orang saksi, dilampirkan surat keterangan pemakaman dari Kantor Pemakaman setempat. Surat keterangan waris. Surat keterangan Pajak Bumi dan bangunan (PBB) terakhir.

Apabila tanahnya belum dibukukan sesuai dengan ketentuan $\mathrm{Pa}$ sal 42 ayat (2) PP No. 24 tahun

\footnotetext{
${ }^{20}$ Urip Santoso, 2015, Perolehan Hak atas tanah, Prenadamedia, Jakarta, Hlm.161
} 
1997 yang berbunyi sebagai berikut:"jika bidang tanah yang merupakan warisan belum didaftar, wajib diserahkan juga dokumen-dokumen sebagaimana dimaksud dalam Pasal 39 ayat (1) huruf b" Dokumen yang membuktikan adanya hak atas tanah pada yang mewariskan diperlukan setelah pendaftaran untuk pertama kali hak yang bersangkutan atas nama yang mewariskan. Hal tersebut dijelaskan dalam Penjelasan Pasal 42 ayat (2) PP Nomor 24 tahun 1997 tentang pendaftaran Tanah. Dari ketentuan Psal 42 ayat (2) PP Nomor 24 Tahun 1997 di atas maka, Ahli waris harus memperlihatkan surat bukti hak berupa bukti-bukti tertulis, keterangan saksi dan atau pernyataan yang bersangkutan yang kadar kebanarannya oleh panitia Ajudikasi atau Kepala kantor Pertanahan dianggap cukup untuk mendaftar hak, pemegang hak dan hakhak pihak lain yang membebaninya. Surat keterangan yang menyatakan bahwa bidang tanah yang bersangkutan belum bersertifikat dari kantor Pertanahan, atau untuk tanah yang terletak di daerah yang jauh dari kedudukan kantor Pertanahan, dari pemegang hak yang bersangkutan dengan dikuatkan oleh Kepala Desa/Kelurahan. Berdasarkan data butir 1 dan 2 di atas kemudian dibuatkan akta waris oleh Pejabat Pembuat Akta Tanah.

Prosedur pendaftaran perali-han hak atas tanah melalui pewari-san, ahli waris atau pemohon pendaftaran tanah mengajukan permohonan pendaftaran hak atastanah melalui pewarisan kepada Kepala Kantor Pertanahan Kabupaten/Kota yang wilayah kerjanya meliputi letak tanah yang bersangkutan. Dalam pendaftaran tanah ini disertakan oleh pemohon berupa: Surat Kematian atas nama pemegang hak atas tanah sebagai pewaris yang diterbitkan oleh instansi yang berwenang, Surat Tanda Bukti sebagai Ahli Warisyang diterbitkan oleh instansi yang berwenang, Bukti identitas ahli waris KTP yang masih berlaku, Surat Kuasa dan photo copy KTP penerima kuasa bila dikuasakan, Wasiat dari pewaris; atau Putusan pengadilan; atau Surat Keterangan ahili Waris yang dibuat oleh para ahli waris dengan disaksikan oleh 2 (dua orang saksi dan dikuatkan oleh Lurah atau Camat, Akta Pembagian hak Bersama dibuat oleh Pejabat Pembuat Akta Tanah apabila ada pembagian harta warisan, Pajak Bumi dan Bangunan tahun terakhir. Sertifikat hak atas tanah yang menjadi objek pewarisan. Kepala Kantor Pertanahan Kabupaten/kota yang wilayah kerjanya meliputi letak tanah yang bersangkutan melakukan perubahan nama pemegang hak atas tanah dalam sertifikat hak atas tanah dari atas nama pewaris menjadi atas nama ahli waris. Kepala Kantor Pertanahan Kabupaten/Kota yang wilayah kerjanya meliputi letak tanah yang bersangkutan menyerahkan sertifikat hak atas tanah kepada pemohon pendaftaran tanah melalui pewarisan.

\section{B. Kesimpulan}

Pendaftaran peralihan hak karena pewarisan mengenai bidang tanah hak yang sudah didaftar dan hak milik atas satuan rumah susun, wajib diserahkan oleh yang menerima hak atas tanah atau hak milik atas satuan rumah susun yang bersangkutan sebagai warisan kepada Kantor Pertanahan, dengan persyaratan sertipikat hak yang bersangkutan, surat kematian orang yang namanya dicatat sebagai pemegang haknya dan surat tanda bukti sebagai ahli waris. Jika bidang tanah ya- 
ng merupakan warisan belum didaftar, wajib diserahkan surat tanda bukti sebagai ahli waris. Jika penerima warisan lebih dari satu orang dan waktu peralihan hak tersebut didaftarkan disertai dengan akta pembagian waris yang memuat keterangan bahwa hak atas tanah atau hak milik atas satuan rumah susun tertentu jatuh kepada seorang penerima warisan tertentu, pendaftaran peralihan hak atas tanah atau hak milik atas satuan rumah susun itu dilakukan kepada penerima warisan yang bersangkutan berdasarkan surat tanda bukti sebagai ahli waris dan akta pembagian waris tersebut.Warisan berupa hak atas tanah atau hak milik atas satuan rumah susun yang menurut akta pembagian waris harus dibagi bersama antara beberapa penerima warisan atau waktu didaftarkan belum ada akta pembagian warisnya, didaftar peralihan haknya kepada para penerima waris yang berhak sebagai hak bersama mereka berdasarkan surat tanda bukti sebagai ahli waris dan/atau akta pembagian waris tersebut Berdasarkan permohonan Ahli waris maka Kepala Kantor Pertanahan Kabupaten/Kota yang wilayah kerjanya meliputi letak tanah yang bersangkutan menyerahkan sertifikat hak atas tanah kepada pemohon pendaftaran tanah melalui pewarisan.

\section{DAFTAR PUSTAKA}

\section{Buku}

Adrian Sutedi, 2014, Peralihan Hak Atas Tanah dan Pendaftarannya, Sinar Grafika, Jakarta .

A.P Parlindungan, 2001, Berakhirnya Hak-Hak Atas Tanah Menurut Sistem UUPA, cetakan III, Mandar Maju, Bandung.

Soerojo Wignjodipoero, 1995. Pengantar dan Azas-Azas Hukum Adat, Haji Masagung, Jakarta.

Urip Santoso, 2015. Perolehan Hak Atas Tanah, Prenadamedia Group, Jakarta.

Prodjojo Hamidjojo, 2000. Hukum Waris Indonesia, Stensil, Jakarta.

\section{Peraturan Perundang-Undangan}

Kitab Undang-Undang Hukum Perdata

Undang-Undang Nomor 5 Tahun 1960 Tentang Peraturan Dasar Pokok-pokok Agraria

Peraturan Pemerintah Nomor 10 Tahun 1961 Tentang Pendaftaran Tanah

Peraturan Pemerintah Nomor 24 Tahun 1997 Tentang Pendaftaran Tanah.

Peraturan Pemerintah Nomor 37 Tahun 1998 tentang Peraturan Jabatan Pejabat Akta Tanah

Surat Direktur pendaftaran tanah, direktur Jenderal Agraria Departemen Dalam Negeri Nomor DPT/12/63/12/69 